\title{
Phytochemical composition, antibacterial and antioxidant activities of the ethanolic root extract of the endemic Onosma, northern Iran.
}

Parsa Pahlavan ( $\sim$ parsapahlavan753@yahoo.com )

University of Mazandaran

Homan Babanejad

University of Mazandaran

Shahab S. Band

National Yunlin University of Science and Technology

\section{Research Article}

Keywords: Disk diffusion method, DPPH assay, Flavonoid content, GC.MS analysis, Phenol content, Onosma dichroantha

Posted Date: February 15th, 2022

DOI: https://doi.org/10.21203/rs.3.rs-1353931/v1

License: (c) (1) This work is licensed under a Creative Commons Attribution 4.0 International License. Read Full License 


\section{Abstract}

This experimental study was performed for determining the antioxidant and antibacterial bioactivity of Onosma dichroantha's root extract obtained using ethanol as our solvent. The results showed that phthalic acid, di(2-propylpentyl) ester (54.52\%), .beta.-sitosterol (16.65\%) and ethanol, 2-(butylamino)$(13.32 \%)$ were the major compounds of the ethanolic root extract of 0 . dichroantha. Total phenols was determined by the Folin-ciocalteu method and the flavonoid content was determined by the colorimetric aluminum chloride method. The maximum phenolic (139.2 $\pm 0.25 \mathrm{mg}$ gallic acid equivalents/ $\mathrm{g}$ of root powder) and flavonoid (17.6 $\pm 0.12 \mathrm{mg}$ quercetin equivalents/ $\mathrm{g}$ of root powder) contents were measured in the ethanol extract. The antioxidant capacity of the root extract was assessed by the scavenging of 1,1-diphenyl-2-picryl hydrazyl (DPPH) free radicals. It was found that antioxidant activity elevated linearly with an increase in the concentration of the ethanol extract. Furthermore, the inhibition value was rather significant compared to the standard controls. The disk diffusion method was used to determine the antibacterial activity of this extract. Thereby, the ethanolic root extract of $O$. dichroantha exhibited great bioactivity against 11 bacterial species, such as Staphylococcus aureus, Pseudomonas aeruginosa, Enterococcus faecalis, Listeria monocytogenes, Staphylococcus epidermis and Streptococcus pyogenes. In conclusion, the ethanolic root extract of $O$. dichroantha has antioxidant and antimicrobial activities.

\section{Introduction}

The Boraginaceae family has approximately 100 genera and 2000 species in temperate and tropical regions around the world (El-Shazly et al., 1998; Ozgen 2004). Iran is known to be a center of distribution of Onosma and has the maximum concentration of such species. This genus has 150 species distributed across dry, sunny and cliffy habitats, like the Mediterranean area and Central Asia (WILLIS 1973). High diversity centers of this genus include Iran, Anatolia and Central Asia (Tiwari et al., 2011). Many properties of different species of Onosma have been widely studied, especially their bioactive chemical compounds, since they have been applied for a wide range of diseases and injuries in Iranian traditional medicine. Ozgen et al., 2003 extracted the roots of Onosma argentatum and found deoxy shikonin, 3 hydroxy-isovareyl shikonin, acetyl shikonin and 5, 8-0 dimethyl acetyl shikonin. Afterwards, they did an in vitro antimicrobial and antioxidant test on the root extract and Staphylococcus aureus, Bacillus subtilis and Escherichia coli were eventually found to be rather sensitive to this root extract (Ozgen et al., 2003). Burns and wound healing is one of the paramount properties of the roots of $O$. argentatum. Two other species of Onosma that are also used for burns and wound healing are Onosma sericeum and Onosma microcarpum, common in the rural regions of Turkey (Ozgen et al., 2004). The circumvention of experimental oxidative stress, reducing tumor growth and skin carcinogenesis has been experienced when the extract of Onosma echiodes is applied (Sharma et al., 2004).

Several secondary metabolites have been extracted from this family that show antibacterial and antioxidant activities, such as alkaloids, naphthoquinones, polyphenols, phytosterols, terpenoids and fatty acids (Li et al., 2010). As we know, phenolic components, like flavonoids, phenolic acids and naphthoquinones like alkannin and shikonin have antioxidant, antiviral, anti-inflammatory and antibiotic 
activities which could be the cause of its wound healing property (Li et al., 2010). Moreover, it has been well-known that treatment with the extracts from different portions of this plant can be beneficial to ameliorating rheumatism, kidney irritation, hemorrhoids, heart palpitation, stomach ulcers and burn wounds (Salman et al., 2009; Ahmad et al., 2009). Black seeds, red-white or yellow flowers and hairy leaves are some of the prominent recognition characters of Onosma dichroantha. The roots of this plant have been described as similar to a red-colored finger. It has been proven that the aerial parts of this plant have emmenagogue and anti-diarrhea activities. To mitigate the liver and spleen pain, and to also treat the different kinds of fever, one must dry and cook this plant before consumption (Safavi et al., 2019). The application of $O$. dichroantha for reducing lymph node inflammation, removing skin spots, injuries and burns is quite common. Some sort of reddish ointment is cooked and prepared by mixing this plant's dried powder with butter in Iranian traditional medicine. The roots of this plant always have a stronger pharmaceutical effect than the aerial parts. (Safavi et al., 2019). To the best of our knowledge, there have been no studies carried out on the evaluation of antimicrobial and antioxidant activities of $O$. dichroantha's root extract collected from the Mazandaran province of Iran.

The aim of this work was to investigate the inhibition effects of the ethanolic root extract of $O$. dichroantha on 16 different species of pathogenic bacteria causing common diseases. At the same time, the antioxidant properties of the extract were determined. The phytochemical components in the extract were also identified for understanding the mechanism of antibacterial and antioxidant activities. Accordingly, to bridge the gap in studies run on the subject of investigation.

\section{Materials And Methods}

\section{Extract preparation}

In this experimental study, the roots of Onosma dichroantha were collected from Alasht, Mazandaran, Iran $\left(36.0665^{\circ} \mathrm{N}, 52.8339^{\circ} \mathrm{E}\right)$ at the altitude of $1908 \mathrm{~m}$. This plant was identified by Dr. Alireza Naghinezhad, Faculty member of university of Mazandaran. The roots were dried at room temperature and coarsely ground before extraction. Powdered roots $(50 \mathrm{~g})$ of 0 . dichroantha were extracted with 1000 $\mathrm{ml}$ of pure ethanol via the maceration method for 48 hours in a mechanical shaker at room temperature. Extracts were filtered with filter paper (Whatman No. 1) and were stored at $4^{\circ} \mathrm{C}$. Eventually, the extract was concentrated over a rotary vacuum evaporator to yield a solid extract sample.

\section{Determination of total phenol content}

Folin Ciocalteu reagent $(2.5 \mathrm{ml}, 0.2 \mathrm{~N})$ was applied to the extract samples ( $0.5 \mathrm{ml}$ of different dilutions) and mixed for 5 minutes. Next, an aqueous $\mathrm{Na}_{2} \mathrm{CO}_{3}\left(2 \mathrm{ml}, 1 \mathrm{~g} . \mathrm{l}^{-1}\right)$ was prepared and applied to the mixture. The mixture was set aside for 2 hours before utilizing the colorimetry at $760 \mathrm{~nm}$ for the 
determination of the phenolic compounds. Based on the solutions of gallic acid, the standard curve was made. Gallic acid equivalent ( $\mathrm{mg}^{-\mathrm{g}^{-1}}$ of dry mass) is the term used for expressing the values of total phenolic compounds (Ghasemi et al., 2015).

\section{Determination of total flavonoid content}

The method chosen for flavonoid determination was the colorimetric aluminum chloride method. In summary, $0.1 \mathrm{ml}$ of aluminum chloride $(10 \%), 1.5 \mathrm{ml}$ of methanol, $0.1 \mathrm{ml}$ of potassium acetate $(1 \mathrm{M})$ and $2.8 \mathrm{ml}$ of distilled water were applied to $0.5 \mathrm{ml}$ of the ethanolic root extract of $O$. dichroantha and mixed. In the next step, the mixture was put at room temperature for about 30 minutes. Double beam Perkin Elmer UV/Visible spectrophotometer was utilized and set at $415 \mathrm{~nm}$ in order to determine the mixture's absorbance. Total flavonoid content was calculated as quercetin from a calibration curve. Quercetin solutions were prepared so that the calibration curve could be determined (Ghasemi et al., 2015).

\section{DPPH radical-scavenging activity}

The ethanolic root extract's free radical-scavenging activity was investigated by making use of 1,1diphenyl-2-picryl hydrazyl radical (DPPH) (Tiwari et al., 2013). Firstly, $1 \mathrm{ml}$ of DPPH methonolic solution with a concentration of $0.1 \mathrm{mM}$ was prepared and equal volumes of the ethanolic root extract with various concentrations were added to it. Afterwards, the mixture was set aside for 15 minutes at room temperature and the spectrophotometer was set at $517 \mathrm{~nm}$ for recording the absorbance of the mixture. The percentage of DPPH scavenging by the extract was calculated applying the formula:

$\%$ Inhibition $=\frac{[\text { Absorbance of control }- \text { Absorbance of extract }]}{[\text { Absorbance of control }]} \times 100$

We used butylated hydroxyanisole (BHA) and ascorbic acid as our standard controls. The test was repeated for three times. In order to scavenge 50 percent of the DPPH free radicals, $\mathrm{IC}_{50}$ values determine the concentration of the sample (Tiwari et al., 2013).

\section{Antibacterial activity}

In order to determine the antibacterial activity of the ethanolic root extract of 0 . dichroantha, 16 different species of Gram-positive and Gram-negative bacteria were tested (Table 1). The bacteria were collected from the Iranian Research Organization for Science and Technology.

The antibacterial activity of the 0 . dichroantha root extract was investigated by taking advantage of the disk diffusion method (Somaranthna et al., 2018). Firstly, concentrations of $25 \mathrm{mg} \cdot \mathrm{ml}^{-1}, 50 \mathrm{mg} \cdot \mathrm{ml}^{-1}, 75$ $\mathrm{mg} \cdot \mathrm{ml}^{-1}$ and $100 \mathrm{mg} \cdot \mathrm{ml}^{-1}$ of the extract were prepared with the usage of ethanol as our solvent. Then, 5 to 10 colonies of bacteria were grown in $1-2 \mathrm{ml}$ Muller Hinton Broth at $37^{\circ} \mathrm{C}$ for $24 \mathrm{~h}$. The content was centrifuged at $1000 \mathrm{~g}$ for 10 min to yield the bacterial pellet. The supernatant was removed, and the bacterial pellet was re-suspended in $1 \mathrm{ml}$ sterile $0.85 \% \mathrm{NaCl}$. Then the content solution was serially 
diluted by adding $9 \mathrm{ml}$ of sterile $0.85 \mathrm{NaCl}$ solution to obtain $5 \times 10^{5} \mathrm{CFU} \mathrm{ml}^{-1}$, and $100 \mathrm{ml}$ of diluted bacterial suspension was spread on Mueller Hinton Agar (MHA) plates. An aliquot $(150 \mathrm{ml})$ of each concentration of the extract was pipetted onto a sterile paper disc of $6 \mathrm{~mm}$ diameter (Whatman No1) on the agar surface. The plates were inverted and incubated at $37^{\circ} \mathrm{C}$ for $24 \mathrm{~h}$.

Microbial inhibition was determined by measuring the clear zone of inhibition around each disc and recorded as the diameter zone of inhibition in millimeters. All assays performed independently three times with triplicates (Somaranthna et al., 2018). Consequently, the yielded data were analyzed by taking advantage of SPSS software (version 19.0; SPSS Inc., Chicago, IL, USA) using the one-way ANOVA test and the $p$-value $<0.05$ was considered to be significant difference.

\section{GC.MS analysis}

The chemical components of ethanolic root extract of $O$. dichroantha were investigated by gas chromatography-mass spectrometry (GC-MS). GC/MS was carried out using a HewlettPackard 5975B series instrument and an Agilent 19091 J-433 HP-5 capillary column (30 m., $250 \mu \mathrm{m}$ i.d., film thickness $0.25 \mu \mathrm{m}$ ) which was set at $50^{\circ} \mathrm{C}$ for $10 \mathrm{~min}$, then increased $4^{\circ} \mathrm{C} / \mathrm{min}$ to $300^{\circ} \mathrm{C}$; using helium as a carrier gas at a flow rate of $1 \mathrm{ml} / \mathrm{min}$. The split ratio was 1:10; ionization energy was $70 \mathrm{eV}$; scan time was $1 \mathrm{~s}$; acquisition mass range was $\mathrm{m} / \mathrm{z} 40-400$. The compounds were identified according to their retention indexes and by comparison of their mass spectra with those of a computer library or with authentic compounds.

\section{Results And Discussion}

\section{Antimicrobial activity}

The results of the present study shows that the ethanolic root extract of 0 . dichroantha originated from ethanol as our solvent has had a good potential for antibacterial activity. Nevertheless, the antimicrobial activity against bacterial organisms varied based on the different types of bacterial species. The results indicated that the extract has inhibitory effect on Staphylococcus aureus, Pseudomonas aeruginosa, Streptococcus pneumoniae, Streptococcus agalactiae, Enterococcus faecalis, Escherichia coli, Shigella sonnie, Shigella flexteriae, Listeria monocytogenes, Staphylococcus epidermis and Streptococcus pyogenes was observed in the ethanolic root extract. Zarghami et al., (2012) in an in vitro study with various extracts of Onosma dichroantha boiss, showed that the ethanolic extract of Onosma's aerial parts had the strongest antimicrobial activity compared to all other extracts. Nonetheless, Sezik et al., (1997) found out that three species of Onosma were active against different bacterial and fungal species. However, these authors demonstrated that the antimicrobial activities may be different according to both the Onosma species and the test organism. The antibacterial results of this study was in accordance with 
the afore-mentioned studies and the extract in general showed more inhibitory effect on Gram-positive bacteria.

Phenolic compounds have tremendous morphological and physiological essentiality in plants and are considered prime phytochemicals (zlotek et al., 2016). It has been reported that phenolic compounds have a key role in the biological activity and inhibitory effect on bacteria (Zain et al., 2012). Moreover, plants synthesize flavonoid compounds in response to bacterial infection. Many endophytes produce flavonoids, probably as antibacterial agents along with phenols (Anitha et al., 2017). Therefore, the flavonoids and phenols, existing in the root and aerial parts of the plant, may contribute to the enhancement of the antimicrobial capacity of the Onosma extract.

Overall, the ethanolic root extract showed antibacterial activities on most of the bacteria and didn't have any effect on some of them, including; Enterobacter aerogenes, Proteus mirabilis and Acinobacter buamannii,. And it had slight inhibitory effect on Klebisella pneumoniae and Salmonella typhi. 
Table 1

Zone of inhibition affected by 0 . dichroantha plant root extract using the disc diffusion method.

\begin{tabular}{|c|c|c|c|c|c|c|c|}
\hline & $\begin{array}{l}\text { Indicator } \\
\text { organisms }\end{array}$ & ATCC & $\begin{array}{l}\text { Pure } \\
\text { ethanol } \\
\text { (Mean } \\
\pm \text { SD) }\end{array}$ & $\begin{array}{l}25 \\
\text { mg.ml-1 } \\
\text { of the } \\
\text { crude } \\
\text { extract } \\
\text { (Mean } \pm \\
\text { SD) }\end{array}$ & $\begin{array}{l}50 \\
\text { mg.ml-1 } \\
\text { of the } \\
\text { crude } \\
\text { extract } \\
\text { (Mean } \pm \\
\text { SD) }\end{array}$ & $\begin{array}{l}75 \\
\text { mg.ml-1 } \\
\text { of the } \\
\text { crude } \\
\text { extract } \\
\text { (Mean } \pm \\
\text { SD) }\end{array}$ & $\begin{array}{l}100 \\
\text { mg.ml-1 } \\
\text { of the } \\
\text { crude } \\
\text { extract } \\
\text { (Mean } \pm \\
\text { SD) }\end{array}$ \\
\hline \multirow{15}{*}{$\begin{array}{l}\text { Zone of } \\
\text { inhibition } \\
\text { (DIZ)/(mm) }\end{array}$} & $\begin{array}{l}\text { Enterococcus } \\
\text { faecalis }\end{array}$ & 29212 & $\begin{array}{l}6 \pm \\
0.00\end{array}$ & $\begin{array}{l}8.7 \pm \\
0.57\end{array}$ & $\begin{array}{l}11.3 \pm \\
1.15\end{array}$ & $\begin{array}{l}12.3 \pm \\
2.08\end{array}$ & $\begin{array}{l}16.3 \pm \\
1.52\end{array}$ \\
\hline & $\begin{array}{l}\text { Streptococcus } \\
\text { pyogenes }\end{array}$ & 19615 & $\begin{array}{l}6 \pm \\
0.00\end{array}$ & $6 \pm 0.00$ & $6 \pm 0.00$ & $\begin{array}{l}8.6 \pm \\
1.15\end{array}$ & $\begin{array}{l}12.6 \pm \\
1.52\end{array}$ \\
\hline & $\begin{array}{l}\text { Streptococcus } \\
\text { pneumoniae }\end{array}$ & 6305 & $\begin{array}{l}6 \pm \\
0.00\end{array}$ & $8 \pm 0.00$ & $\begin{array}{l}10.6 \pm \\
0.57\end{array}$ & $\begin{array}{l}9.6 \pm \\
2.31\end{array}$ & $12 \pm 1.15$ \\
\hline & $\begin{array}{l}\text { Streptococcus } \\
\text { agalactiae }\end{array}$ & 12386 & $\begin{array}{l}6 \pm \\
0.00\end{array}$ & $6 \pm 0.00$ & $6 \pm 0.00$ & $6 \pm 0.00$ & $\begin{array}{l}11.6 \pm \\
0.58\end{array}$ \\
\hline & $\begin{array}{l}\text { Staphylococcus } \\
\text { aureus }\end{array}$ & 25923 & $\begin{array}{l}6 \pm \\
0.00\end{array}$ & $\begin{array}{l}11.3 \pm \\
1.53\end{array}$ & $\begin{array}{l}13 \pm \\
1.00\end{array}$ & $\begin{array}{l}15 \pm \\
1.73\end{array}$ & $\begin{array}{l}17.3 \pm \\
1.15\end{array}$ \\
\hline & $\begin{array}{l}\text { Staphylococcus } \\
\text { epidermis }\end{array}$ & 12228 & $\begin{array}{l}6 \pm \\
0.00\end{array}$ & $6 \pm 0.00$ & $\begin{array}{l}7.3 \pm \\
0.56\end{array}$ & $\begin{array}{l}10.6 \pm \\
1.15\end{array}$ & $14 \pm 0.57$ \\
\hline & $\begin{array}{l}\text { Listeria } \\
\text { monocytogenes }\end{array}$ & 7644 & $\begin{array}{l}6 \pm \\
0.00\end{array}$ & $6 \pm 0.00$ & $8 \pm 0.00$ & $\begin{array}{l}9.6 \pm \\
1.53\end{array}$ & $\begin{array}{l}15.3 \pm \\
1.15\end{array}$ \\
\hline & Escherichia coli & 25922 & $\begin{array}{l}6 \pm \\
0.00\end{array}$ & $6 \pm 0.00$ & $6 \pm 0.00$ & $\begin{array}{l}6.6 \pm \\
1.15\end{array}$ & $\begin{array}{l}7.3 \pm \\
1.15\end{array}$ \\
\hline & $\begin{array}{l}\text { Klebisella } \\
\text { pneumoniae }\end{array}$ & 13883 & $\begin{array}{l}6 \pm \\
0.00\end{array}$ & $6 \pm 0.00$ & $6 \pm 0.00$ & $6 \pm 0.00$ & $\begin{array}{l}6.6 \pm \\
1.15\end{array}$ \\
\hline & $\begin{array}{l}\text { Enterobacter } \\
\text { aerogenes }\end{array}$ & 13048 & $\begin{array}{l}6 \pm \\
0.00\end{array}$ & $6 \pm 0.00$ & $6 \pm 0.00$ & $6 \pm 0.00$ & $6 \pm 0.00$ \\
\hline & $\begin{array}{l}\text { Proteus } \\
\text { mirabilis }\end{array}$ & 43071 & $\begin{array}{l}6 \pm \\
0.00\end{array}$ & $6 \pm 0.00$ & $6 \pm 0.00$ & $6 \pm 0.00$ & $6 \pm 0.00$ \\
\hline & $\begin{array}{l}\text { Pseudomonas } \\
\text { aeroginosa }\end{array}$ & 27853 & $\begin{array}{l}6 \pm \\
0.00\end{array}$ & $6 \pm 0.00$ & $8 \pm 0.00$ & $\begin{array}{l}9.3 \pm \\
1.15\end{array}$ & $\begin{array}{l}15.6 \pm \\
1.15\end{array}$ \\
\hline & $\begin{array}{l}\text { Salmonella } \\
\text { typhi }\end{array}$ & 14028 & $\begin{array}{l}6 \pm \\
0.00\end{array}$ & $6 \pm 0.00$ & $6 \pm 0.00$ & $6 \pm 0.00$ & $\begin{array}{l}6.6 \pm \\
1.15\end{array}$ \\
\hline & Shigella sonnie & 9220 & $\begin{array}{l}6 \pm \\
0.00\end{array}$ & $6 \pm 0.00$ & $6 \pm 0.00$ & $7 \pm 0.00$ & $\begin{array}{l}8.6 \pm \\
0.58\end{array}$ \\
\hline & $\begin{array}{l}\text { Shigella } \\
\text { flexteriae }\end{array}$ & 12022 & $\begin{array}{l}6 \pm \\
0.00\end{array}$ & $6 \pm 0.00$ & $6 \pm 0.00$ & $6 \pm 0.00$ & $7 \pm 1.00$ \\
\hline
\end{tabular}




\begin{tabular}{|c|c|c|c|c|c|c|}
\hline $\begin{array}{l}\text { Indicator } \\
\text { organisms }\end{array}$ & ATCC & $\begin{array}{l}\text { Pure } \\
\text { ethanol } \\
\text { (Mean } \\
\pm \text { SD) }\end{array}$ & $\begin{array}{l}25 \\
\text { mg.ml-1 } \\
\text { of the } \\
\text { crude } \\
\text { extract } \\
\text { (Mean } \pm \\
\text { SD) }\end{array}$ & $\begin{array}{l}50 \\
\text { mg.ml-1 } \\
\text { of the } \\
\text { crude } \\
\text { extract } \\
\text { (Mean } \pm \\
\text { SD) }\end{array}$ & $\begin{array}{l}75 \\
\text { mg.ml-1 } \\
\text { of the } \\
\text { crude } \\
\text { extract } \\
\text { (Mean } \pm \\
\text { SD) }\end{array}$ & $\begin{array}{l}100 \\
\text { mg.ml-1 } \\
\text { of the } \\
\text { crude } \\
\text { extract } \\
\text { (Mean } \pm \\
\text { SD) }\end{array}$ \\
\hline $\begin{array}{l}\text { Acinobacter } \\
\text { buamannii }\end{array}$ & $\begin{array}{l}\text { BAA- } \\
747\end{array}$ & $\begin{array}{l}6 \pm \\
0.00\end{array}$ & $6 \pm 0.00$ & $6 \pm 0.00$ & $6 \pm 0.00$ & $6 \pm 0.00$ \\
\hline
\end{tabular}

In order to answer the research question of the study, the one-way ANOVA test was used for mean comparison. The descriptive statistics of the groups are shown below.

Table 2

The descriptive statistics for the comparison of the control and the experimental groups.

\begin{tabular}{|lllllll|}
\hline & $\mathbf{N}$ & Mean & Std. Deviation & Std. Error & Minimum & Maximum \\
\hline Pure ethanol & 16 & 6.00 & 0.00 & 0.00 & 6.00 & 6.00 \\
\hline $\mathbf{2 5} \mathrm{mg} \cdot \mathrm{ml}^{-1}$ & 16 & 6.62 & 1.48 & 0.37 & 6.00 & 11.30 \\
\hline $\mathbf{5 0} \mathrm{mg} \cdot \mathrm{ml}^{-1}$ & 16 & 7.38 & 2.26 & 0.56 & 6.00 & 13.00 \\
\hline $\mathbf{7 5} \mathrm{mg} \cdot \mathrm{ml}^{-1}$ & 16 & 8.16 & 2.73 & 0.68 & 6.00 & 15.00 \\
\hline $\mathbf{1 0 0} \mathrm{mg} \cdot \mathrm{ml}^{-1}$ & 16 & 10.55 & 4.21 & 1.05 & 6.00 & 17.30 \\
\hline Total & 80 & 7.74 & 2.95 & 0.32 & 6.00 & 17.30 \\
\hline
\end{tabular}

The extracted means of the pure ethanol as the control group of study, $25 \mathrm{mg} \cdot \mathrm{ml}^{-1}, 50 \mathrm{mg} \cdot \mathrm{ml}^{-1}, 75$ mg.ml ${ }^{-1}$ and $100 \mathrm{mg}^{-\mathrm{ml}^{-1}}$ are $6,6.62,7.38,8.16,10.55$ and 7.74 , respectively. The result of the one-way ANOVA test for the comparison of the groups is presented below.

Table 3

The result of the one-way ANOVA test for the comparison of the control and the experimental groups.

\begin{tabular}{|llllll|}
\hline & Sum of Squares & df & Mean Square & F & Sig. \\
\hline Between Groups & 199.51 & 4 & 49.87 & 7.65 & .00 \\
\hline Within Groups & 488.50 & 75 & 6.51 & & \\
\hline Total & 688.01 & 79 & & & \\
\hline
\end{tabular}

According to the Table 3 above, there was a statistically significant difference among the groups regarding their mean scores, $F(4,75)=7.65, p<.05$. Hence, the researcher safely rejects the null 
hypothesis. The following table (Tukey) compares the groups individually. 
Table 4

The result of the pairwise comparison of the groups.

\begin{tabular}{|c|c|c|c|c|c|c|}
\hline \multirow[t]{2}{*}{ (I) Groups } & \multirow[t]{2}{*}{ (J) Groups } & \multirow{2}{*}{$\begin{array}{l}\text { Mean Difference (I- } \\
\text { J) }\end{array}$} & \multirow{2}{*}{$\begin{array}{l}\text { Std. } \\
\text { Error }\end{array}$} & \multirow[t]{2}{*}{ Sig. } & \multicolumn{2}{|c|}{$95 \%$ Confidence Interval } \\
\hline & & & & & $\begin{array}{l}\text { Lower } \\
\text { Bound }\end{array}$ & $\begin{array}{l}\text { Upper } \\
\text { Bound }\end{array}$ \\
\hline \multirow{4}{*}{$\begin{array}{l}\text { Pure } \\
\text { ethanol }\end{array}$} & $25 \mathrm{mg}_{\mathrm{ml}} \mathrm{m}^{-1}$ & -0.62 & 0.90 & 0.95 & -3.14 & 1.89 \\
\hline & $50 \mathrm{mg} \mathrm{ml}^{-1}$ & -1.38 & 0.90 & 0.54 & -3.90 & 1.13 \\
\hline & $75 \mathrm{mg} \mathrm{ml}^{-1}$ & -2.16 & 0.90 & 0.12 & -4.68 & 0.35 \\
\hline & ${ }_{1}^{100} \mathrm{mg} \cdot \mathrm{ml}^{-}$ & $-4.55^{\star}$ & 0.90 & 0.00 & -7.07 & -2.02 \\
\hline \multirow[t]{4}{*}{$25 \mathrm{mg} \cdot \mathrm{ml}^{-1}$} & $\begin{array}{l}\text { Pure } \\
\text { ethanol }\end{array}$ & 0.62 & 0.90 & 0.95 & -1.89 & 3.14 \\
\hline & $50 \mathrm{mg} \cdot \mathrm{ml}^{-1}$ & -0.76 & 0.90 & 0.91 & -3.28 & 1.75 \\
\hline & $75 \mathrm{mg} \mathrm{ml}^{-1}$ & -1.53 & 0.90 & 0.43 & -4.05 & 0.98 \\
\hline & ${ }_{1}^{100} \mathrm{mg} \cdot \mathrm{ml}^{-}$ & $-3.92^{*}$ & 0.90 & 0.00 & -6.44 & -1.40 \\
\hline \multirow[t]{4}{*}{$50 \mathrm{mg} \mathrm{ml}^{-1}$} & $\begin{array}{l}\text { Pure } \\
\text { ethanol }\end{array}$ & 1.38 & 0.90 & 0.54 & -1.13 & 3.90 \\
\hline & $25 \mathrm{mg} \cdot \mathrm{ml}^{-1}$ & 0.76 & 0.90 & 0.91 & -1.75 & 3.28 \\
\hline & $75 \mathrm{mg} \mathrm{ml}^{-1}$ & -0.77 & 0.90 & 0.91 & -3.29 & 1.74 \\
\hline & ${ }_{1}^{100} \mathrm{mg} \mathrm{ml}^{-}$ & $-3.16^{\star}$ & 0.90 & 0.00 & -5.68 & -0.64 \\
\hline \multirow[t]{4}{*}{$75 \mathrm{mg} \mathrm{ml}^{-1}$} & $\begin{array}{l}\text { Pure } \\
\text { ethanol }\end{array}$ & 2.16 & 0.90 & 0.12 & -0.359 & 4.68 \\
\hline & $25 \mathrm{mg} \cdot \mathrm{ml}^{-1}$ & 1.53 & 0.90 & 0.43 & -0.984 & 4.05 \\
\hline & $50 \mathrm{mg} \mathrm{ml}^{-1}$ & 0.77 & 0.90 & 0.91 & -1.74 & 3.29 \\
\hline & ${ }_{1}^{100} \mathrm{mg} \mathrm{ml}^{-}$ & -2.38 & 0.90 & 0.07 & -4.90 & 0.13 \\
\hline \multirow[t]{3}{*}{${ }_{1}^{100} \mathrm{mg} \cdot \mathrm{ml}^{-}$} & $\begin{array}{l}\text { Pure } \\
\text { ethanol }\end{array}$ & $4.55^{\star}$ & 0.90 & 0.00 & 2.02 & 7.07 \\
\hline & $25 \mathrm{mg} \mathrm{ml}^{-1}$ & $3.92^{*}$ & 0.90 & 0.00 & 1.40 & 6.44 \\
\hline & $50 \mathrm{mg} \mathrm{ml}^{-1}$ & $3.16^{*}$ & 0.90 & 0.00 & 0.64 & 5.68 \\
\hline
\end{tabular}



$75 \mathrm{mg} \cdot \mathrm{ml}^{-1}$
2.38
0.90
0.07
$-0.13$
4.90

As Table 4 shows, there was a significant difference between the pure ethanol and $100 \mathrm{mg} \cdot \mathrm{ml}^{-1}$ groups $(p<.05)$; there was a significant difference between the $25 \mathrm{mg} \cdot \mathrm{ml}^{-1}$ and $100 \mathrm{mg} \cdot \mathrm{ml}^{-1} \mathrm{groups}(\mathrm{p}<.05)$; there was a significant difference between the $50 \mathrm{mg} \cdot \mathrm{ml}^{-1}$ and $100 \mathrm{mg}^{\mathrm{ml}} \mathrm{m}^{-1} \mathrm{groups}(\mathrm{p}<.05)$.

\section{Total phenolic and flavonoid content}

In the present experiment, the total phenolic and flavonoid content of 0 . dichroantha's ethanolic root extract is $139.2 \pm 0.25 \mathrm{mg} . \mathrm{g}^{-1}$ and $17.6 \pm 0.12 \mathrm{mg} . \mathrm{g}^{-1}$, respectively. According to the results, a quite high phenolic content was observed in the ethanol extract. Similarly, a high total flavonoid content was determined in the ethanol extract. Several studies demonstrated that the genus Onosma is a great source of phytochemical constituents like phenolic compounds (Lakenbrink et al., 2000)(Özgen et al., 2003)( Grzegorczyk et al., 2006). The optimization of extraction factors of the phenolic content and antioxidant properties of plant-based foods are a major concern, as some studies have concluded. However, different plant material commonly have variety in an optimal procedure (Rababah et al., 2010). Data on the total flavonoid content of the $\boldsymbol{O}$. dichroantha's root extract are limited in the literature. Therefore, the comparisons were made with the other species of the onosma genus. The result of the present study confirms the one conducted by Zarghami Moghaddam et al., (2012) reporting that the ethanol root extract of onosma genus had a remarkable value of total flavonoid compounds (Zarghami Moghaddam et al., 2012). Moreover, the primary phytochemical screening of three species of onosma revealed that the total flavonoid compounds were a major part of their total chemical composition (Zarghami Moghaddam et al., 2012).

\section{Antioxidant activity}

In the present experiment, the antioxidant activity of the ethanolic root extract was determined by scavenging of the DPPH free radicals. The inhibition value as shown in Table 5 below, was found in the ethanol extract.

It is well-known that solvent polarity plays a key part in increasing phenolic solubility. Therefore, ethanol was chosen as the solvent (Naczk et al., 2006; Alothman et al., 2009). Hence, the most appropriate solvent for extraction of the roots is ethanol or a solution based on water and ethanol (Tomsone et al., 2012). The $\mathrm{IC}_{50}$ of the standard control compounds, $\mathrm{BHA}$ and ascorbic acid were $106.82 \pm 0.40 \mu \mathrm{g} \cdot \mathrm{ml}^{-1}$ and $189.04 \pm 0.02 \mu \mathrm{g} \cdot \mathrm{ml}^{-1}$, respectively. Since $\mathrm{IC}_{50}$ is inversely associated with the anti-radical activity of the compounds, the lower the $\mathrm{IC}_{50}$, the higher the antioxidant activity (Noroozi et al., 2017). The $\mathrm{IC}_{50}$ of the DPPH radical-scavenging activity of the ethanolic root extract of $O$. dichroantha was $263.271 \pm 0.02$ $\mu \mathrm{g} \cdot \mathrm{ml}^{-1}$ which is higher than but close to both the $\mathrm{IC}_{50}$ of ascorbic acid and the $\mathrm{IC}_{50}$ of BHA. In summary, the ethanolic root extract of $O$. dichroantha has a high antioxidant activity. 
Table 5

DPPH radical-scavenging activity of ascorbic acid, BHA and the 0 . dichroantha root extract

\begin{tabular}{|llll|}
\hline $\begin{array}{l}\text { Concentration } \\
\left(\mu \mathrm{g} \cdot \mathrm{ml}^{-1} \text { ) }\right.\end{array}$ & $\begin{array}{l}\text { Radical scavenging } \\
\text { activity (\%) of ascorbic } \\
\text { acid }\end{array}$ & $\begin{array}{l}\text { Radical } \\
\text { scavenging activity } \\
(\%) \text { of BHA }\end{array}$ & $\begin{array}{l}\text { Radical scavenging activity (\%) } \\
\text { of the O. dichroantha root extract }\end{array}$ \\
\hline 800 & $96.4 \pm 0.7$ & $95.5 \pm 0.001$ & $76.12 \pm 0.03$ \\
\hline 400 & $71.2 \pm 0.2$ & $93.2 \pm 0.002$ & $62.32 \pm 0.04$ \\
\hline 200 & $55.1 \pm 0.1$ & $72.8 \pm 0.01$ & $47.74 \pm 0.07$ \\
\hline 100 & $44.8 \pm 0.4$ & $43.7 \pm 0.03$ & $39.65 \pm 0.02$ \\
\hline 50 & $38.7 \pm 0.2$ & $28.2 \pm 0.02$ & $19.62 \pm 0.02$ \\
\hline
\end{tabular}

\section{Chemical composition}

In the present experiment, the chemical composition of the ethanolic root extract of 0 . dichroantha was determined and the results are presented in Table 6 The primary phytochemical screening showed that phthalic acid, di(2-propylpentyl) ester (54.52\%), .beta.-sitosterol (16.65\%), benzene, 1-hexyl-4-nitro$(4.89 \%)$ and cyclohexanone, (4-nitrophenyl) hydrazone (4.09\%) were the major compounds of the ethanolic extract. Phthalic acid, di(2-propylpentyl) ester is known to be antimicrobial, Cytotoxic and antiinflammatory (Cotter et al., 2005)( Habib et al., 2009). Beta.-sitosterol is another major compound in the extract which has strong antioxidant activities and it also reduces thiobarbituric acid reactive substances (Gupta et al., 2011)( Upadhyay et al., 2012). However, the antimicrobial activities of this compound are still controversial and quite dubious (Sen et al., 2012)(Cota et al., 2003)( Gohari et al., 2009)( Mishra et al., 2010)( Bayor et al., 2009). A cyclohexanone derivative is another major compound in the extract which belongs to a paramount group of six-membered heterocyclic compounds that are known to have antibacterial activities against both Gram-Negative and Gram-positive bacteria (Asiri et al., 2011). Consequently, several major compounds in the 0 . dichroantha's root extract are responsible for its antibacterial activities against different bacterial species as shown in Fig. 1. 
Table 6

The major compounds found in the ethanolic root extract of 0 . dichroantha.

\begin{tabular}{|llll|}
\hline No & Name of composition & RT & AREA (\%) \\
\hline 1 & Ethanol, 2-(butylamino)- & 17.671 & 13.32 \\
\hline 2 & Phthalic acid, di(2-propylpentyl) ester & 23.112 & 54.52 \\
\hline 3 & Acetamide, N-tricyclco [4.3.1.1(3,8)] undec-1-yl- & 23.603 & 2.90 \\
\hline 4 & Benzene, 1-hexyl-4-nitro- & 23.637 & 4.89 \\
\hline 5 & Cyclohexanone, (4-nitrophenyl) hydrazone & 24.561 & 4.09 \\
\hline 6 & Pregan-12-one, (5.beta.)- & 24.596 & 3.63 \\
\hline 7 & Beta.-sitosterol & 31.024 & 16.65 \\
\hline
\end{tabular}

\section{Conclusion}

The ethanolic root extract of Onosma dichroantha collected from the North of Iran has significant antibacterial and antioxidant activities, which could be because of its main chemical components such as phthalic acid and beta. -sitosterol. In fact, the ethanolic root extract of $O$. dichroantha can be a paramount source for pharmaceutical applications. Staphylococcus aureus, Pseudomonas aeruginosa, Enterococcus faecalis, Listeria monocytogenes, Staphylococcus epidermis and Streptococcus pyogenes are some the bacteria that were highly sensitive to this extract and do not show any growth in its presence. Nonetheless, the ethanolic extract displayed high concentrations of phenol and flavonoid contents and a quite elevated scavenging of DPPH free radicals in different concentrations. Nevertheless, our knowledge of the many extraordinary properties of this plant at the molecular level is limited and needs further studies to see if it has anticancer, antifungal, anti-inflammatory or other properties as well.

\section{Declarations}

\section{Acknowledgments}

We wish to show our appreciation to Dr. Morad Bagherzadeh Kasmani (English Language Department, Faculty of Language and Literature, Chalous Branch, Islamic Azad University, Chalous, Iran) for his invaluable comments that greatly improved the manuscript, both in English language and in methodology.

\section{Funding information}

This research did not receive any specific grant from funding agencies in the public, commercial, or notfor-profit sectors. 
Authors contribution

P.P \& H.B ; Root sampling, phenol assay, flavonoid assay, DPPH assay, Disk diffusion antibacterial assay, GC.MS analysis. S.S.B ; Data analysis.

\section{References}

Ahmad A, Ali N, Bashir S, Choudhary MI, Azam S, Khan I. 2009. Parasiticidal, anti- fungal and antibacterial activities of Onosma griffithii Vatke. Afr. J. Biotechnol. 8: 5084-5087.

A.K. Tiwari, K. Manasa, D.A. Kumar, A. Zehra, Raw horse gram seeds possess more in vitro antihyperglycaemic activities and antioxidant properties than their sprouts, Nutrafoods 12 (2) (2013) 4754 .

Alksne LE, Projan SJ. 2000. Bacterial virulence as a target for antimicrobial chemotherapy. Curr Opin Biotechnol 11: 625-636.

Alothman M, Bhat R, Karim A. 2009. Antioxidant capacity and phenolic content of selected tropical fruits from Malaysia, extracted with different solvents. Food Chem 115(3): 785-8.

Asiri AM, Khan SA. 2011. Synthesis and antibacterial activities of a bis-chalcone derived from thiophene and its bis-cyclized products. Molecul 16 (1): 523- 531.

Anitha KU, Mythili S. 2017. Antioxidant and hepatoprotective potentials of novel endophytic fungus Achaetomium sp. from Euphorbia hirta. Asi Pacif Jour of Tropic Medic 10(6): 588-93.

Bayor MT, Gbedema SY, Anna K. 2009. The antimicrobial activity of Croton membranaceus, a species used in formulations for measles in Ghana. J Pharmacogn Phytother. 1:47-51.

Bumrela S, Naik S. 2012. Hepato protective activity of methanolic extract of Dipteracanthus patulus (Jacq)Nees: Possible involvement of antioxidant and membrane stabilization property. Int. J. Pharm. Pharm. Sci 4: 685-690.

Cota BB, Oliveira AD, Souza-Filho JD, Braga FC. 2003. Antimicrobial activity and constituents of Coccoloba acrostichoides. Fitoterap. 74: 729-31.

Cotter PD, Hill C, Ross RP. 2005. Food microbiology: bacteriocins: developing innate immunity for food. Nat Rev Micro biol 3(10): 777-788.

El-Shazly A, El-Domiaty M, Witte L, Wink M. 1998. Pyrrolizidine alkaloids in members of the Bpranginaceae from Sinai (Egypt). Biochem. Syst Ecol 26: 619-636.

Gohari AR, Saeidnia S, Shahverdi AR, Yassa N, Malmir M, Mollazade K, Naghinejad AR. 2009. Phytochemistry and antimicrobial compounds of Hymenocrater calycinus. Eur Asia J BioSci 3: 64-8. 
Grzegorczyk I, Matkowski A, Wysokińska H. 2007. Antioxidant activity of extracts from in vitro cultures of Salvia officinalis L. Food Chem 104(2): 536-41.

Gupta R, Sharma AK, Dobhal MP, Sharma MC, Gupta RS. 2011. Antidiabetic and antioxidant potential of beta-sitosterol in streptozotocin-induced experimental hyperglycemia. J Diabetes 3: 29-37.

Habib MR, Karim MR. 2009. Antimicrobial and cytotoxic activity of di- (2-ethylhexyl) phthalate and anhydrosophoradiol-3-acetate isolated from Calotropis gigantea (Linn.) flower. Mycobiology 37: 31-36.

Kanokmedhakul K, Kanokmedhakul S, Phatchana R. 2005. Biological activity of anthraquinones and triterpenoids from Prismatomeris fragrans. J. Ethnopharmacol 100: 284-288.

K Ghasemi, S Bolandnazar, SJ Tabatabaei, H Pirdashti, M Arzanlou, MA Ebrahimzadeh \& H Fathi (2015)Antioxidant properties of garlic as affected by selenium and humic acid treatments, New Zealand Journal of Crop and Horticultural Science, 43:3, 173-181

Lakenbrink C, Lapczynski S, Maiwald B, Engelhardt UH. 2000. Flavonoids and Other Polyphenols in Consumer Brews of Tea and Other Caffeinated Beverages. J Agricultu Food Chem. 48(7): 2848-52.

Li L, Li MH, Xu LJ, Guo N, Wu-Lan TN, Shi RB, Pei-Gen Xiao YP. 2010. Distribution of seven polyphenols in several medicinal plants of Boraginaceae in China. J. Med. Plants Res 4(12): 1216-1221.

Mazandarani M, Zarghami Moghaddam P, Zolfaghari MR, Ghaemi EA, Bayat H. 2012. Effects of solvent type on phenolics and flavonoids content and antioxidant activities in Onosma dichroanthum Boiss. Journ of medic plan resear 6(28): 4481-448.

Mishra BB, Singh DD, Kishore N, Tiwari VK, Tripathi V. 2010. Antifungal constituents isolated from the seeds of Aegle marmelos. Phytochem 71: 230-4.

Naczk M, Shahidi F. 2006. Phenolics in cereals, fruits and vegetables: Occurrence, extraction and analysis. Journ of Pharm and Biomed Anal 41(5): 1523-1542.

Noroozi, A., Yousefzadeh, S., Kamal Sadat Aslan, K. \& Mansourifar, S. Evaluation of Changes in Essential Oil, Chlorophyll, Carotenoid, Anthocyanins, and Flavonoids of Mentha longifolia (L.) Huds. subsp. longifolia in di erent habitats of Marand. J. Ecoph. Med Plants. 5, 52-64 (2017).

Oh KB, Oh MN, Kim JG, Shin DS, Shin,J. 2006. Inhibition of sortase-mediated Staphylococcus aureus adhesion to fibronectin via fibronectin-binding protein by sortase inhibitors. Appl. Microbiol. Biotechnol 70: 102-106.

Koyuncu O, Koray O, Ozgisi K, Sezer O, Ozturk D. 2013. A New Onosma (Boranginaceae) species from central Anatolia, Turkey. Plant Sys and Evol 299: 1839-1847. 
Ozgen U, Coskun M, Kazaz C, Secen H. 2004. Naphthoquinones from the roots of Onosma argenta- tum. Turk. J. Chem 28: 451-454.

Özgen U, Houghton PJ, Ogundipe Y, Coşkun M. 2003. Antioxidant and antimicrobial activities of Onosma argentatum and Rubia peregrina. Fitoterap 74(7-8): 682-5.

Patra, A, Jha S, Murthy PN, Manik Sharone A. 2010. Isolation and characterization of stigmast-5-en-3ß-ol ( $\beta$-sitosterol) from the leaves of Hygrophila spinosa. Int. J. Pharm. Sci. Res 2: 95-100.

Zarghami Moghaddam P, Mazandarani M, Zolfaghari MR, Badeleh MT, Ghaemi EA. 2012. Antibacterial and antioxidant activities of root extract of Onosma dichroanthum Boiss. in north of Iran. Afric Journ of Micro Researc 6(8): 1776-1781.

Safavi F, Farimani MM, Golalipour M, Leung PC, Lau KM, Kwok HF, Wong CW, Bayat H, Lau CBS. 2019. Investigations on the wound healing properties of Onosma dichroantha Boiss root extracts 125: 344-352.

Salman S, Kumbasar S, Ozgen U, Erdogan F, Suleyman H. 2009. Contraceptive effects of Onosma armeniacum on embryo implantation in rats. Cell Membr. Free Radic 1(3): 90-94.

Sen A, Dhavan P, Khukla KK, Singh S, Tejovathi G. 2012. Analysis of IR, NMR and antimicrobial activity of $\beta$-sitosterol isolated from Momordica charantia. Sci Secure J Biotechnol 1(1): 9-13.

Sezik E, Silada EY, Tabata M, Honda G, Takaishi Y, Fujita T, Tanaka T, Takeda Y. 1997. Traditional Medicine in Turkey VIII. Folk Medicine in East Anatolia; Erzurum, Erzincan, Agri, Kars, Igdir Provinces Ekrem. Econ. Bot. 51: 195-211

Shahina N, Samia A, Sheikh AR, Syed AS, Rahmanullah S. 2006. Antibacterial activity directed isolation of compounds from Onosma hispidum. Micro Researc 161(1): 43-48.

Sharma S, Khan K, Sultana S. 2004. Effect of Onosma echiodes on DMBA/croton oil mediated carvcinogenic response, hyperproliferation and oxidative damage in murine skin. Life Sci 75(20): 23912410

Nabavi SM, Ebrahimzadeh MA, Nabavi SF. 2008. Antioxidant and free radical scavenging activity of metabolic extract of Pterocarya fraxinifolia (Lam.) spach leaves and bark. Iran Jour of Medic and Arom Plant 24, No. 3.

Rababah TM, Banat F, Rababah A, Ereifej K, Yang W. 2010. Optimization of extraction conditions of total phenolics, antioxidant activities, and anthocyanin of oregano, thyme, terebinth, and pomegranate. Journ of Food Sci 75(7): 626-632.

Tiwari UKL, Adhikari BS, Rawat GS. 2011. On the recollection and rediscovery of Onosma pyramidale Hook. f., Boraginaceae from Chamoli, Uttarakhand. Asian J Pharm Life Sci 1(4):406-408. 
T. Somarathna, W.M.A.D.B. Fernando, K.K.D.S. Ranaweera, G.A.S. Premakumara, T. Abeysinghe, N.S. Weerakkody, Antimicrobial activity and phytochemical screening of Alpinia malaccensis (Ran-kiriya) against food-borne bacteria, J. Appl. Microbiol. 125 (2018) 1276-1285.

Kundakovic T, Fokialakis N, Dobric S, Pratsinis H, Kletsas D, Kovacevic N, Chinou I. 2006. Evaluation of the anti-inflammatory and cytotoxic activities of naphthazarine derivatives from Onosma leptantha. Phytomed 13(4): 290-294.

Nezamdoost T, Bagherieh-Najjar MB , Aghdasi M. 2014. Biogenic synthesis of stable bioactive silver chloride nanoparticles using Onosma dichroantha Boiss. root extract. Mat Let 137: 225-228.

Tomsone L, Kruma Z, Galoburda R. 2012. Comparison of different solvents and extraction methods for isolation of phenolic compounds from horseradish roots (Armoracia rusticana). Wrld Acadmy of Sci and Engine Technol 64:903-8.

Upadhyay K, Gupta NK, Dixit VK. 2012. Development and characterization of phyto-vesicles of betasitosterol for the treatment of androgenetic alopecia. Arch Dermatol Res 304: 511-9.

Złotek U, Mikulska S, Nagajek M, S' wieca M. 2016 The effect of different solvents and number of extraction steps on the polyphenol content and antioxidant capacity of basil leaves (Ocimum basilicum L.) extracts. Saud Journ of Bio Sci. 23(5): 628-633.

Kolarcik V, Martonfri P. 2006. Revision of the distribution of the genus Onosma (Boranginaceae) in Slovakia. Thai Journ of Bota 16: 131-154

WILLIS JC. 1973. A dictionary of the flowering plants and ferns. - Cambridge University Press, Cambridge, pp. 1236.

Zain ME, Awaad AS, Al-Outhman MR, El-Meligy RM. 2012. Antimicrobial activities of Saudi Arabian desert plants. Phytopharma 2(1):106-13.

\section{Figures}



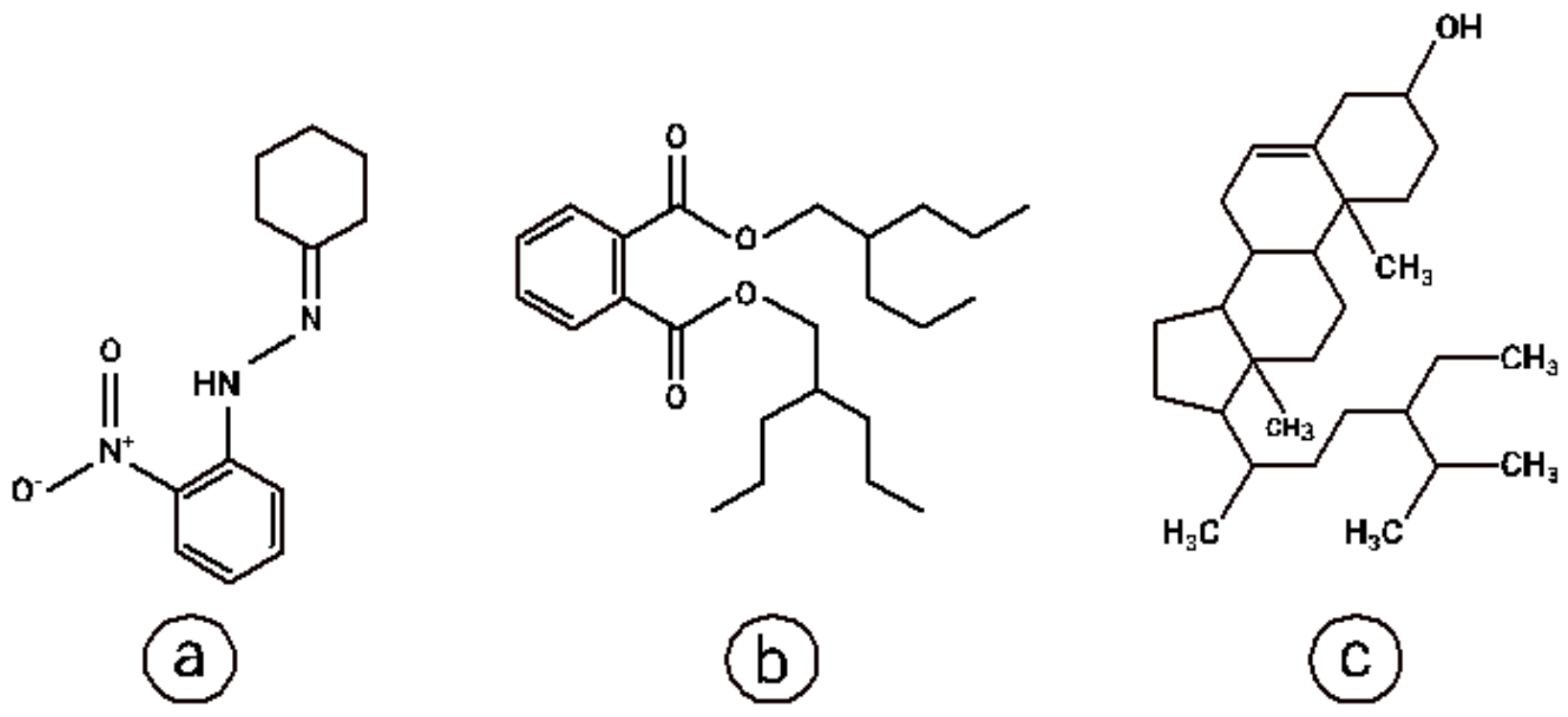

\section{Figure 1}

Chemical structures of the discussed compounds;

a) Cyclohexanone, (4-nitrophenyl) hydrazone

b) Phthalic acid, di(2-propylpentyl) ester

c) Beta.-sitosterol 